\title{
Extra-Axial Cerebello-Pontine Angle Medulloblastoma
}

\section{Meduloblastoma extra-axial no ângulo ponto-cerebelar}

\author{
Rodrigo Moreira Faleiro ${ }^{1}$ Vítor Vieira de Souza Moraes ${ }^{1}$ Maria Teresa de Seixas Alves ${ }^{1}$ \\ Moises Salgado Pedrosa ${ }^{1}$ Luiz Alberto Otoni Garcia ${ }^{1}$ Renato Rinco Fontoura ${ }^{1}$ Vanessa Alves Lobato ${ }^{1}$ \\ Diego Silveira Rodrigues ${ }^{1}$ Laura Vilaça Carvalho Viégas Martins ${ }^{1}$
}

\author{
${ }^{1}$ Department of Neurosurgery, Hospital Felício Rocho, Belo \\ Horizonte, MG, Brazil
}

Arq Bras Neurocir 2016;35:234-238.
Address for correspondence Rodrigo Moreira Faleiro, MD, MSc, Department of Neurosurgery, Hospital Felício Rocho, Belo Horizonte, MG, Brazil (e-mail: r.m.faleiro@hotmail.com).

\section{Abstract \\ Keywords \\ - medulloblastoma \\ - cerebellum \\ - pediatric \\ - children \\ - tumor \\ - neurosurgery}

Medulloblastoma is the most common central nervous system tumor in children. Extraaxial medulloblastomas, especially tumors with no connection to the brain stem or cerebellum are extremely rare. We report a case of a 3-year-old patient, who presented with a history of subacute headache and vomiting. After performing a head computed tomography scan, a mass was detected in the left cerebello-pontine angle, along with concomitant hydrocephalus. The treatment was total resection of the tumor. Despite the fact that extra-axial medulloblastomas are extremely rare, this differential diagnosis should be included in the management of pediatric patients who present with posterior fossa tumors.

Meduloblastoma é o tumor do sistema nervoso central mais comum em crianças. Meduloblastomas extra-axiais, especialmente tumores sem conexão com o tronco encefálico ou cerebelo, são extremamente raros. Relatamos o caso de uma paciente de 3 anos de idade, que apresentou um histórico de cefaleia subaguda e vômitos. Por meio de um exame de tomografia computadorizada, foi identificada uma massa no ângulo ponto-cerebelar esquerdo, acompanhada de hidrocefalia. O tratamento foi resseção total do tumor. Apesar de meduloblastomas extra-axiais serem extremamente raros, este diagnóstico diferencial deve ser incluído no manejo de pacientes pediátricos que apresentem tumores da fossa posterior.

\section{Introduction}

Medulloblastoma is the most common central nervous system tumor in children, ${ }^{1-3}$ and accounts for $\sim 22 \%$ of the malignant tumors in the pediatric population. ${ }^{4,5}$ In the United States, the incidence of this neoplasia is 0.6 per 100,000 patients no more than 14 years old, and accounts for $17 \%$ of all brain tumors in this group. There appears to be a bimodal age distribution in children, with peaks at ages 3 to 4 years and at ages 8 to 9 years. ${ }^{1}$ Extraaxial medulloblastomas, especially tumors with no connection to the brain stem or cerebellum are extremely rare. ${ }^{2-6}$ Patients with medulloblastomas usually present with nonspecific clinical signs, often being confused with other tumors that show similar symptoms and imaging exams. ${ }^{3}$ Therefore, we emphasize through this case report, the received

August 16, 2015

accepted

April 8, 2016

published online

June 16, 2016
DOI http://dx.doi.org/

$10.1055 / \mathrm{s}-0036-1584552$. ISSN $0103-5355$.
Copyright $\odot 2016$ by Thieme Publicações License terms Ltda, Rio de Janeiro, Brazil
(ब) $\Theta \circledast$ 


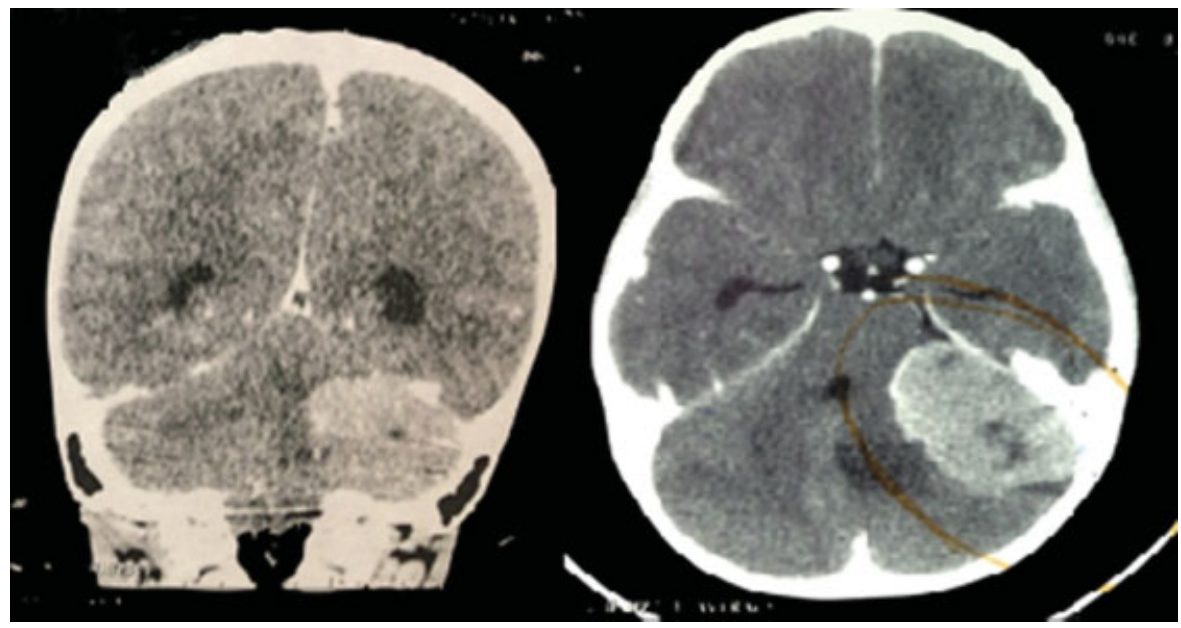

Fig. 1 Preoperative head CT scan, coronal and axial views, showing a mass in the left cerebellopontine angle.

importance of the differential diagnosis of this tumor, when approaching neoplasms located in the posterior fossa, as well as its therapeutic principles.

\section{Case Report}

A 3-year and 11 month-old female patient was taken to the hospital, with a history of subacute headache, which was initially related to sinusitis. She had no previous history of tumor, neither any other disease. Later, the patient developed episodes of vomiting, and a computerized tomography scan was indicated, despite her neurological exam, that was normal. The presence of a mass, located in the posterior fossa, in the left cerebello-pontine angle, was detected, along with concomitant hydrocephalus (-Figs. 1-3). After resolution of intracranial hypertension, with dexamethasone, the patient underwent microsurgical excision of the tumor. The approach was through a left retrosigmoid suboccipital access, identifying a soft, friable, well-defined mass, with a clear arachnoid plane, separating the tumor from the cerebellum, allowing its complete excision. The anatomopathological examination of the lesion confirmed the diagnosis of desmoplastic medulloblastoma (-Fig. 4). The patient evolved with good clinical conditions in early and late postoperative care, in a 12 months follow up, with brain and spine radiologic exams and cerebrospinal fluid (CSF) cytology results negative for any signs of remnant tumor or metastasis (-Figs. 5-7).

\section{Discussion}

Medulloblastoma is a tumor that affects predominantly the pediatric population. ${ }^{2}$ It's a poorly demarcated, pinkpurple, soft friable mass, which arises from the cerebellar vermis, usually from the inferior medullary velum. ${ }^{1,4,7}$ There may be foci of hemorrhage or necrosis, but cysts are unusual. Desmoplastic variants may be more firm, as a result of their greater connective tissue component. ${ }^{1}$ In the

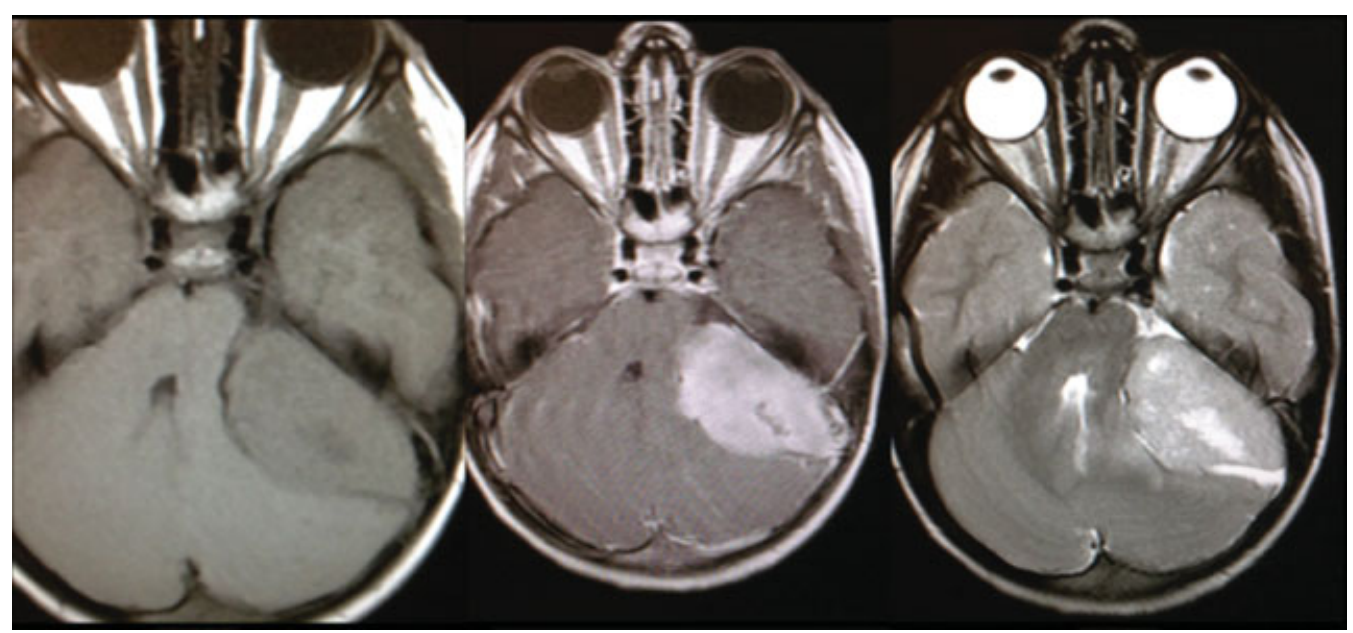

Fig. 2 Preoperative nuclear magnetic resonance imaging exam, axial view, on T1, contrast enhanced T1 and T2 weighted images. 


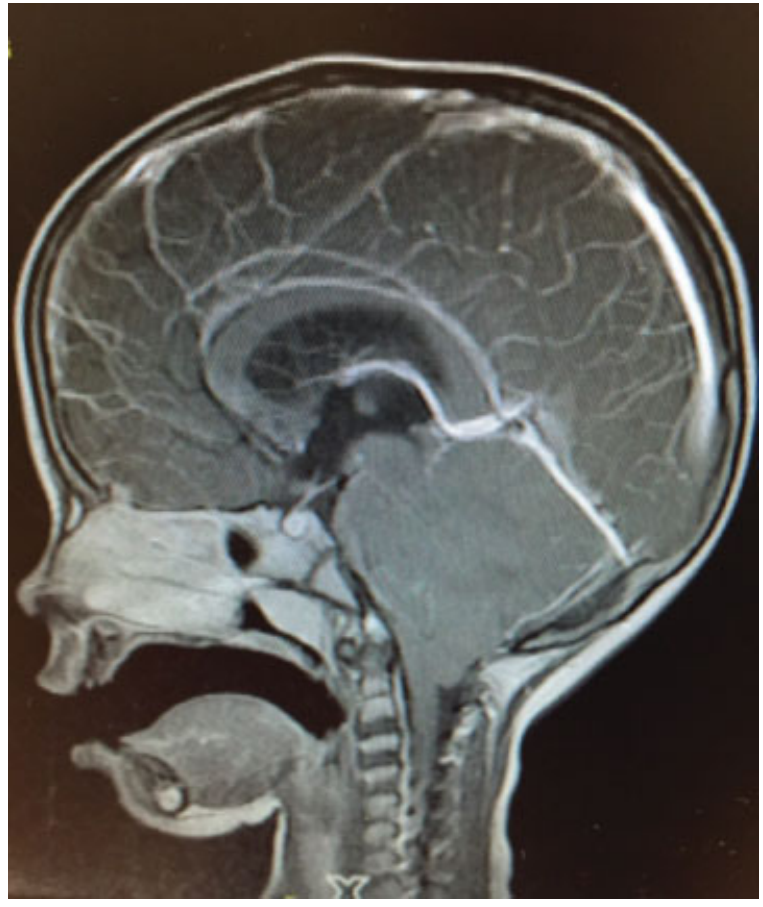

Fig. 3 Preoperative nuclear magnetic resonance imaging exam, sagittal view, showing hydrocephalus (corpus callosum bulging and cerebellar tonsil impaction at the foramen magnum).

early stages of the central nervous system development, the cerebellar progenitor cells arise from two major germinal zones, and generate distinct populations of the neural cells that compose the cerebellum: the peri-ventricular germinal matrix, in the cerebellar plate, over the fourth ventricle, and the external granular layer. ${ }^{5,8}$ As this tumor has a neuroectodermal origin, ${ }^{6,9,10}$ its extra-axial location may be associated to remnants of the neural crest

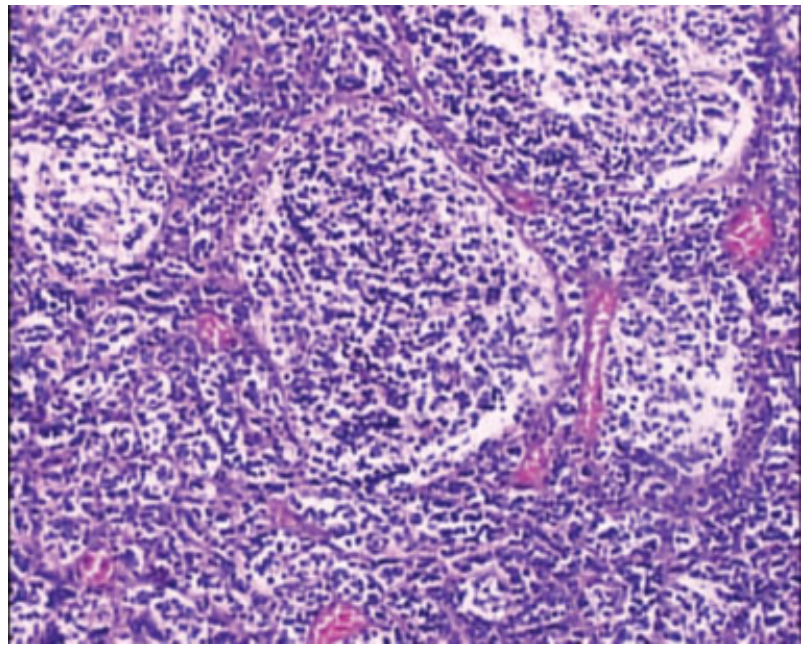

Fig. 4 Histopathological exam of the tumor (desmoplastic medulloblastoma), hematoxylin and eosin stain, 100x magnification.

stem cells, which persisted specifically in the cerebellopontine angle, from where the medulloblastoma arose. The tumor may extend through the fourth ventricle into the aqueduct of Sylvius or into the cisterna magna, through the foramen of Magendie. Involvement of the cerebellar hemispheres is uncommon in children, but is more frequent in adults. Brainstem infiltration is seen in 15 to $40 \%$ of cases. ${ }^{1}$ Medulloblastoma has a strong propensity to metastasize, and the most common site for metastasis is the subarachnoid space. ${ }^{1,3,11}$ There are few cases of medulloblastoma located in the cerebello-pontine angle, with extra-axial location, and this phenomenon is extremely rare., ${ }^{2,3}$

Most children present with the classic triad of morning headache, vomiting and lethargy, but these symptoms are nonspecific. ${ }^{9}$ Cerebellar signs, such as truncal ataxia, limb

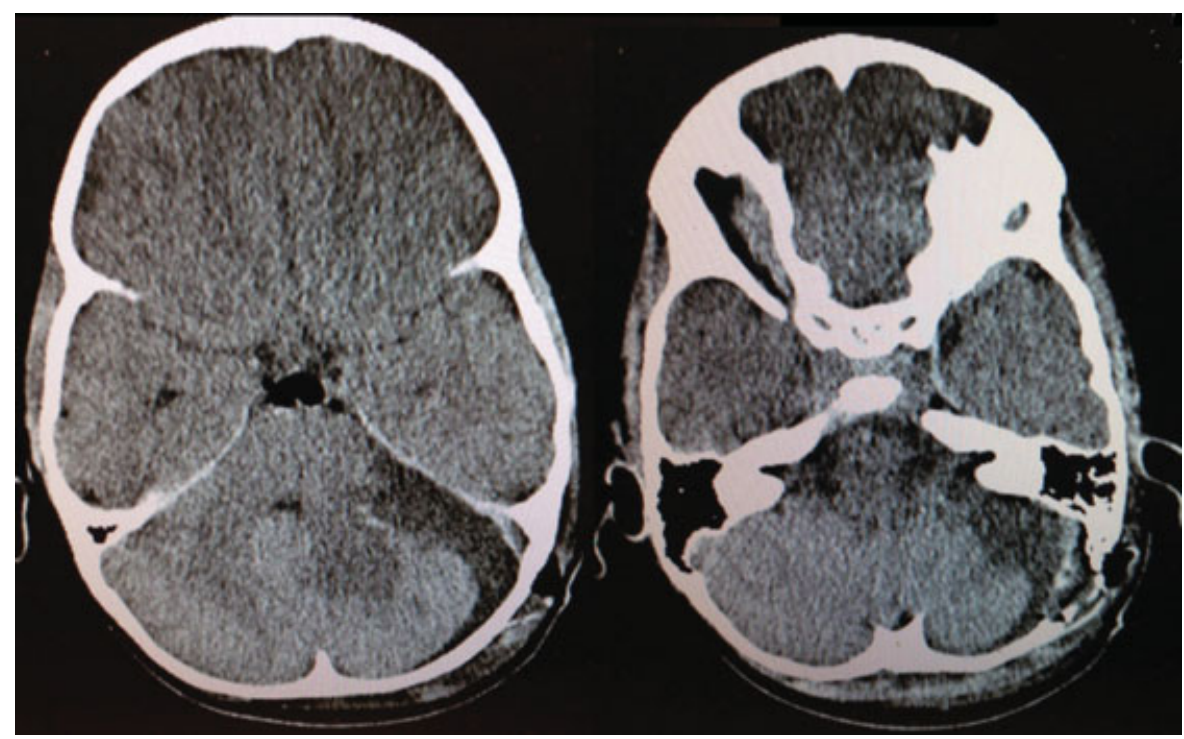

Fig. 5 Postoperative head computed tomography scan, axial view, showing complete resection of the tumor. 


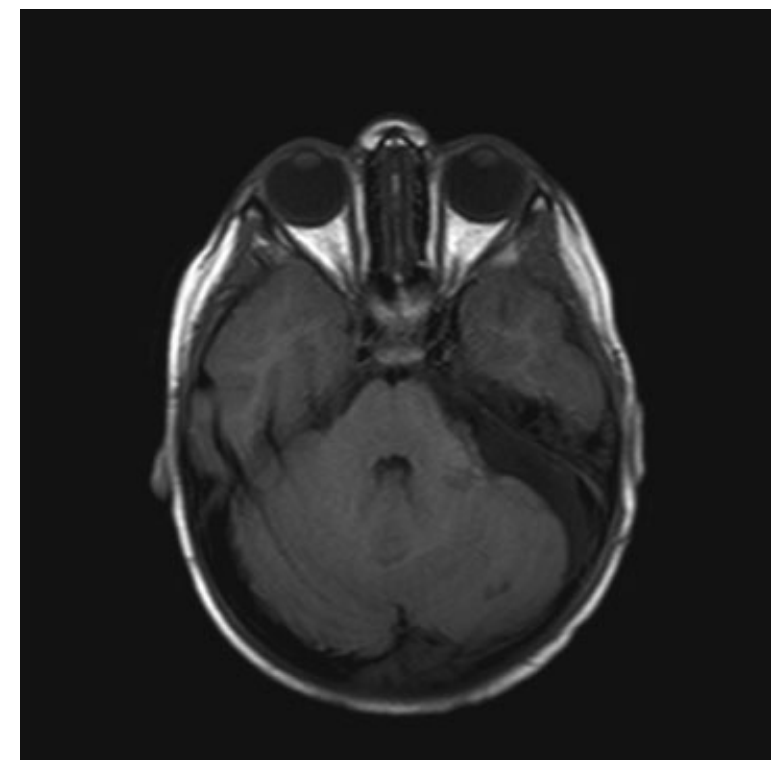

Fig. 6 Postoperative nuclear magnetic resonance imaging exam, axial view, T1 weighted image, showing absence of macroscopic residual tumor.

ataxia, or dysmetria may also occur. Brainstem invasion is suspected if there are bulbar or facial palsies, although sixth nerve palsy is usually a result of hydrocephalus. ${ }^{1}$ It is very important to pay attention to the differential diagnosis of tumors located in the posterior fossa, specifically in the cerebello-pontine angle, including: vestibular neuro-

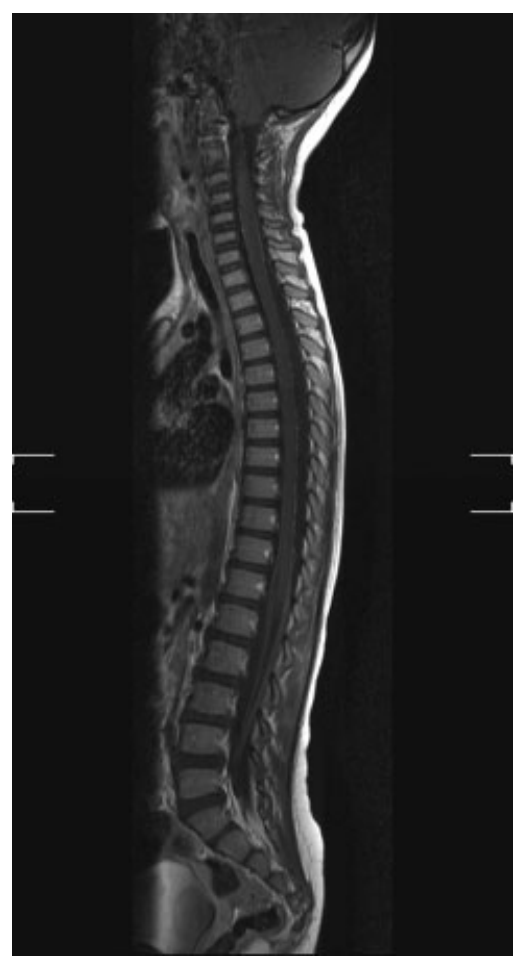

Fig. 7 Postoperative nuclear magnetic resonance neuroaxis imaging, showing absence of macroscopic residual tumor. ma, facial nerve schwannoma, meningioma, ${ }^{12}$ primary cholesteatoma, and epidermoid tumors, among others. ${ }^{13}$ In magnetic resonance imaging (MRI) exams, the medulloblastoma is usually hypointense to gray matter on T1, shows enhancement by Gadolinium, and may be iso- or hyperintense to gray matter on $\mathrm{T} 2^{5,11,12,14}$; vestibular neuromas usually show intermediate signal intensity on T1 weighted images, increased intensity in contrast enhanced T1, and may not be seen in T2; facial nerve schwannoma images are identical to vestibular neuromas in MRI, showing a middle cranial fossa mass, which extends from the internal acoustic canal to the geniculate ganglion; meningiomas are related to increased vascularity, and hypointensity on MRI, when compared with these other tumors; primary cholesteatomas are hypointense in T1 and hyperintense in T2, similar to the cerebrospinal fluid; epidermoid tumors are best seen on T2 weighted images, with different levels of signal intensity, according to the keratin, cholesterol or water content of the tumor. ${ }^{9,14}$ Involvement of the V, VI, VII, VIII, and lower cranial nerves, ${ }^{15}$ and signs of cerebellar disfunction are commonly noted in CP angle lesions. ${ }^{1,3}$ The early onset of signs of cerebellar ataxia may indicate an axial origin of the tumor, while positional nistagmus may be suggestive of acoustic schwannoma. ${ }^{16}$

The goals of surgery are to establish a histologic diagnosis, maximally resect the tumor mass, and promote resolution of hydrocephalus., ${ }^{3,9,11}$ Postoperative radiation and chemotherapy are used to eliminate residual disease. The patients' follow-up is done using brain and spine magnetic resonance imaging and CSF cytology, searching for metastasis or residual disease. 1

\section{Conclusion}

Despite the fact that extra-axial medulloblastomas are extremely rare, this differential diagnosis should be included in the management of patients who present with posterior fossa tumors, especially in the $\mathrm{CP}$ angle. ${ }^{3,4}$ Clinical and radiological exams not often give the definitive diagnosis of the disease. Therefore, this report is of importance to the neurosurgeon, especially in managing the diagnosis on children.

\section{References}

1 Youmans JR. Neurological Surgery. 6th Edition. W.B. Saunders Company; 2011.

2 Yamada S, Aiba T, Hara M. Cerebellopontine angle medulloblastoma: case report and literature review. Br J Neurosurg 1993; 7(1): 91-94

3 Kumar R, Bhowmick U, Kalra SK, Mahapatra AK. Pediatric cerebellopontine angle medulloblastomas. J Pediatr Neurosci 2008; 3(2):127-130

4 Bahrami E, Bakhti S, Fereshtehnejad SM, Parvaresh M, Khani MR. Extra-axial medulloblastoma in cerebello-pontine angle: A report of a rare case with literature review. Med J Islam Repub Iran 2014; 28:57 
5 Fallah A, Banglawala SM, Provias J, Jha NK. Extra-axial medulloblastoma in the cerebellopontine angle. Can J Surg 2009;52(4): E101-E102

6 Gil-Salú JL, Rodríguez-Peña F, López-Escobar M, Palomo MJ. [Medulloblastoma presenting as an extra-axial tumor in the cerebellopontine angle]. Neurocirugia (Astur) 2004;15(3):285-289

7 McLendon RE, Rosenblum MK, Bigner DD, Eds. Russell \& Rubinstein's Pathology of Tumors of the Nervous System. 7th Ed. New York: Oxford University Press Inc.; 2006; 247-260

8 Petritsch C, Vandenberg SR. Stem cells and progenitor cell lineages as targets for neoplastic transformation in the central nervous system. In: Kaye AH, Laws ER Jr. Brain Tumors. 3rd Ed. New York: Elsevier; 2012. Chap. 2. p. 12-15

9 Ciurea AV, Palade C. Medulloblastoma: An Overview. Romanian Neurosurgery. Bucareste 2010;17(3):291-303

10 Frosch MP, Anthony DC, Girolam U. O Sistema Nervoso Central: Tumores. In: Kumar V, Abbas Ak, Fausto N. Robbins \& Cotran Patologia: Bases Patológicas Das Doenças. 8th Ed. São Paulo: Elsevier; 2010(28):1338-1351
11 MacDonald TJ, Rood BR, Santi MR, et al. Advances in the diagnosis, molecular genetics, and treatment of pediatric embryonal CNS tumors. Oncologist 2003;8(2):174-186

12 Meshkini A, Vahedi A, Meshkini M, Alikhah H, Naghavi-Behzad M. Atypical medulloblastoma: A case series. Asian J Neurosurg 2014; $9(1): 45-47$

13 Koeller KK, Rushing EJ. From the archives of the AFIP: medulloblastoma: a comprehensive review with radiologicpathologic correlation. Radiographics 2003;23(6):1613-1637

14 Fruehwald-Pallamar J, Puchner SB, Rossi A, et al. Magnetic resonance imaging spectrum of medulloblastoma. Neuroradiology 2011;53(6):387-396

15 Hubbard JL, Scheithauer BW, Kispert DB, Carpenter SM, Wick MR, Laws ER Jr. Adult cerebellar medulloblastomas: the pathological, radiographic, and clinical disease spectrum. J Neurosurg 1989; 70(4):536-544

16 Holst B, Grunwald IQ, Brill G, Reith W. [Differential diagnosis of space demands in the cerebellopontine angle]. Radiologe 2004; 44(11):1113-1136, quiz 1137 